\title{
СРЕДЊОВЕКОВНИ МАЧ ИЗ ГЛОГОВЦА
}

\author{
Филип Стефановић \\ Завичајни музеј Параћин
}

\author{
e-mail: st.filip@yahoo.com $\mid$ Оригинални научни рад \\ Примљено: 14. 12. 2020. УДК: 904:623.444.2"653"(497.11) \\ Прихваћено: 9. 6. 2021. 069.51:904(497.11)
}

\begin{abstract}
Апстракт: Аутор анализира мач пронађен приликом копања шьунка из Мораве у атару села Глоговаи код Јагодине. Мач је пронађен у добром стаюу мада је багером фрагментован на два дела. Ради се о великом витешком мачу какви су коришћени у средњовековној Европи током 14. века. Припада типу најчешћих налаза дворучних мачева са простора југоисточне Европе. Најкарактеристичнија одлика мача је симбол крста са срием, или цвета, који се налази на сечиву и изведен је тауширањем. Уз морфолошко-типолошку анализу мача, представљене су и географски блиске аналогије, на основу којих је одређен тип и датовање мача. Иако случајан налаз, представља значајно археолошко сведочанство бурне историје простора на коме је нађен, и чини вредан додатак збирии средюовековног наоружања Завичајног музеја ,Параћин”.
\end{abstract}

Кључне речи: Глоговац, Морава, Поморавље, мач, позни средюи век

Током јесени 2016. године, у збирку Завичајног музеја у Параћину, стигао је занимљив налаз. Наиме, током ископавања шљунка из Мораве, у близини села Глоговац код Јагодине радници су пронашли велики средњовековни мач. ${ }^{1}$ Мач је пронађен у врло добром стању, са мало корозије, чак и са траговима дрвета на дршци, мада му недостаје врх. Нажалост, приликом копања шљунка багером, мач је фрагментован на два дела (сл. 1).

Ради се о великом мачу, импозантних димензија. Укупна очувана дужина мача је 127 цм. Најзначајнија карактеристика мача је тауширани симбол на сечиву мача, у коме се може препознати крст са срцем или цвет.

Велики проценат, може се рећи и већина мачева који се тренутно налазе у збиркама музеја у Србији пронађен је у рекама, или на речним обалама, што потврђују и примери из других музеја (Поп Лазић 1983, 190; Радичевић 2009, 77, 78; Марковић 1989а, 154, 155). Ретки су налази мачева који потичу са археолошких ископавања, па је самим тим и изучавање мачева

\footnotetext{
${ }^{1}$ Експлоатацију шљунка је вршила параћинска фирма „Транскоп” па је, захваљујући брзој реакцији запослених у Завичајном музеју у Параћину и општинској управи, пронађени мач поклоњен музеју, где се чува под инвентарним бројем 1941.
} 


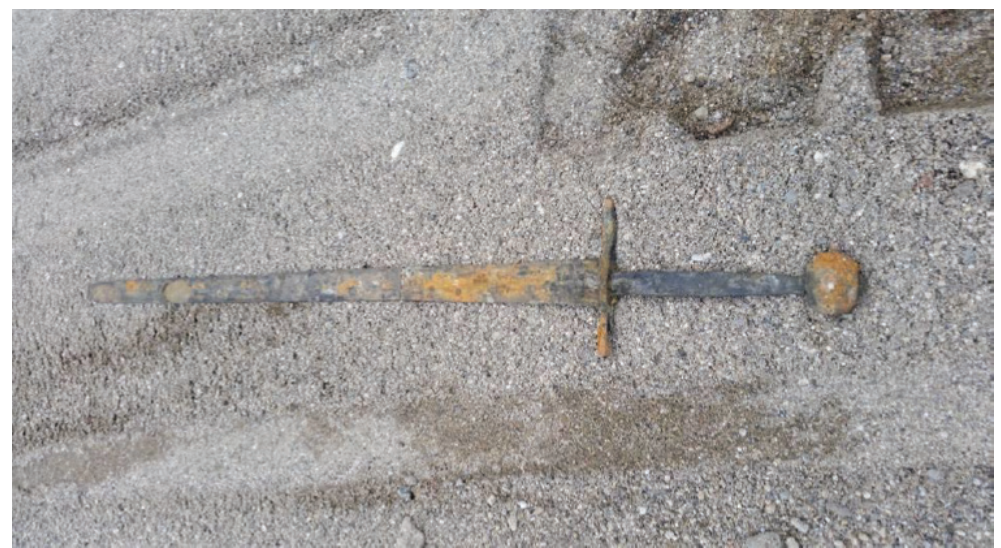

Сл. 1. Мач приликом проналаска у Морави код села Глоговац, документација Завичајног музеја Параћин

Fig. 1. Sword being recovered from the Morava River near the village of Glogovac, documentation of the Hometown Museum in Paraćin

отежано. Углавном недостају основни археолошки подаци, контекст, услови налаза, прецизна локација (Шкриванић 1957, 3; Aleksić 2007, 7). Анализа и проучавање средњовековних мачева, своди се на морфолошко-типолошку и функционалну анализу, уз све чешћу примену физичко-хемијских анализа делова оружја. Типолошка припадност се код мача одређује на основу анализе сечива, рукохвата, јабуке и накрснице (Нинковић 2009, 457).

\section{Морфолошке карактеристике мача и аналогије}

Мач има велико и широко сечиво, очувана дужина сечива је 98 цм, док је дужина целог балчака са накрсницом 29 цм, ширина сечива код накрснице је око 6 цм, док је при врху сечива око 4 цм (сл. 2). Жлеб је дужине око 50 , ширине око 2 цм, и пружа се до половине сечива. Сам врх сечива није очуван. Сечиво је танко, вероватно је додатно истањено приликом оштрења, при накрсници сечиво је дебело 0,6 цм док је на очуваном врху свега 0,2 цм. На основу ових карактеристика, може се претпоставити да сечиво припада типу XIIІа, према типологији коју је поставио Оукшут. Мачеви са сечивом овог типа представљају један од првих типова великих мачева, који су у средњовековној литератури називани „,espées de guerre”, „grant espées”, „grete swerdes" (Oakeshott 1991, 42-46).

Што се тиче простора Балкана и југоисточне Европе, овакви примерци су међу најчешћим налазима мачева, и познато је скоро 70 примерака. Датују се од средине 13. века, мада су највише коришћени током 14. 


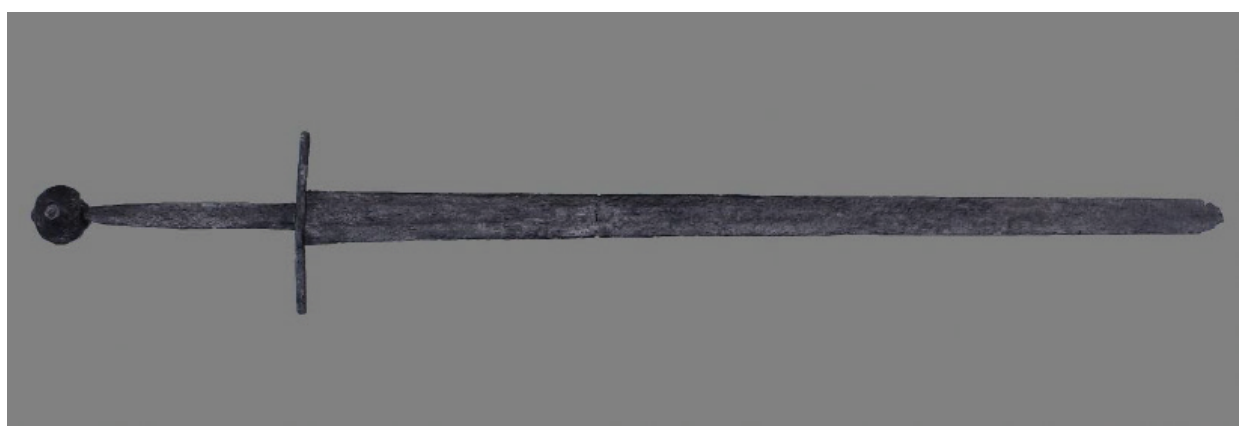

Сл. 2. Мач из Глоговца након конзервације, документација Завичајног музеја Параћин

Fig. 2. Sword from Glogovac after conservation, documentation of the Hometown Museum in Paraćin

века, нарочито у другој половини. Мачеви типа XIIIa и XVIa су највише коришћени дворучни мачеви (Aleksić 2007, 84).

Рукохват и накрсница мача из Глоговца су једноставни (сл. 8). Укупна дужина накрснице је 19 цм, међутим, кракови накрснице нису симетрични у односу на сечиво, односно један је вероватно оштећен, па је дужина једног 7, а другог 6 цм. Дужина целог балчака од јабуке до накрснице је око 29 цм. Сечиво и дршка су исковани из једног дела, као што је углавном био и обичај на средњовековним мачевима (Aleksić 2007, 12), док су накрсница и јабука додати касније. Дршка је отприлике једнаке ширине целом дужином, код накрснице и на средини 2,7 цм, док се уз јабучицу сужава на 1,2 цм. Накрсница је једноставна, на основу морфологије припада Оукшутовом типу 1. Овај тип карактерише једноставност, кракови су четвртастог пресека, приближне ширине и на почетку и на крајевима, благо повијени према сечиву. Крајеви су равни (Oakeshott 1991, 116). Овај тип накрсница се може тешко разликовати на фотографијама или цртежима од накрсница типа 7. Карактеристичне су за читав средњи век, и могу се наћи на мачевима различитих типова (Aleksić, 94, 97).

Јабучица је кружна (сл. 9), а на пљоснатијим странама има купаста испупчења и припада масивнијим типовима јабучица. Пречник јабучице је 6,4 цм у висини, а 5,7 цм у ширини. Ширина јабучице од врха до врха испупчења је 5,3 цм. У основној типолошкој подели јабучица, коју је поставио Британац Оукшут, припада типу К. (Oakeshott 1991, 96), док према подели A. Руткаја припада типу XVII (Ruttkay 1975/76). Марија Шерцер је овај тип назвала $1 \mathrm{~b}$ (Šercer 1976, 10-12). Јабучице овог типа су комплексније од старијих типова (G и H), док се од Оукшутовог типа J, разликује по томе што је средишњи диск тањи, а купаста испупчења су израженија. 


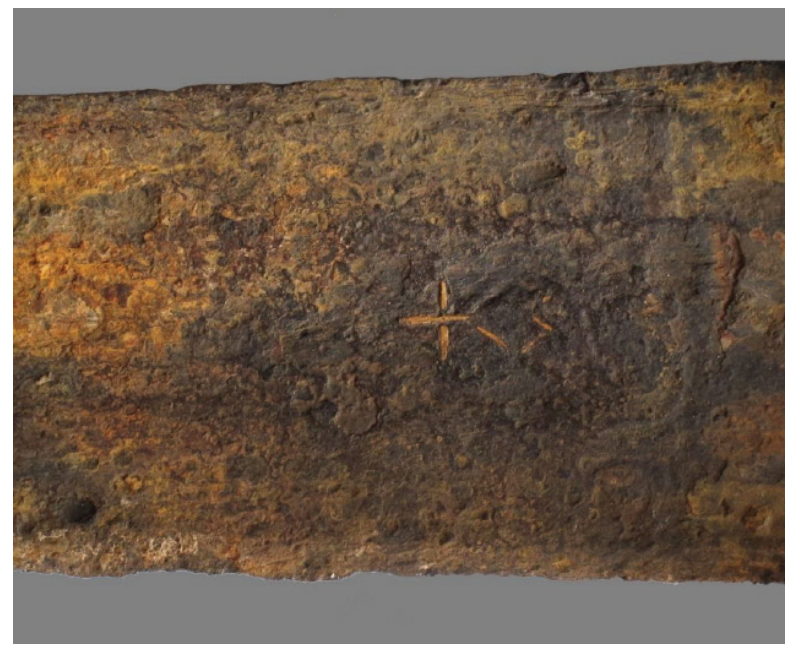

Сл. 3. Тауширани симбол на мачу из Глоговца, пре конзервације, документација Завичајног музеја Параћин

Fig. 3. The inlaid symbol on the sword from Glogovac, before conservation, documentation of the Hometown Museum in Paraćin

Оваква јабучица се јавља на мачевима од средине 13. века, а најчешће у 14. веку. Готово сви мачеви са оваквом јабучицом са простора југоисточне Европе велики су, са сечивима типа XIIIa и XVIa (Aleksić 2007, 55).

Чини се да је јабучица неспретно изведена, врхови купа нису правилни, а и саме купе су помало асиметричне у односу на средишњи диск. Јабучица је вероватно оштећена приликом набијања на трн дршке, пукотина која је вероватно била заливена бронзом се током векова проширила, па јабучици недостаје сам врх диска са једне стране. Закивак на врху јабучице је пирамидалан и релативно правилан.

У самој централној Србији постоји неколико мачева са јабучицом овог типа. Један је пронађен у Дунаву код Вишњице (сл. 10), и припада збирци Музеја града Београда (инв. бр. 1/540). Ради се о дугом, великом, мачу, укупне дужине од 124 цм, са сечивом типа XIIIa дужине 97 цм. За разлику од мача из Глоговца, мач пронађен у Вишњици има тауширане крстове на купастим испупчењима на јабучици. Мач има тауширане симболе и на сечиву, на једној страни знак крста, и у близини вука у трку са отвореним чељустима, док су на другој страни сечива тауширањем изведени знак срца (троугла) и једнорог у трку. Ово је типичан мач „вуковац” и датује се у другу половину 14. века (Birtašević 1968, 81-83) (Aleksić 2007, 54-58).

Сличну јабучицу, има и мач који се налази у збирци Војног музеја у Београду (сл. 11), под инвентарним бројем 21447. Ради се о великом мачу, 
са сечивом типа XV1 и јабучицом типа К. Мачу недостаје накрсница. На јабучици, жицом од легуре бронзе у техници тауширања изведени су симболи грчког крста, док су на сечиву са обе стране у истој техници изведени различити мотиви, цвет са осам латица, латински крст, хералдички штит и један непрепознатљив симбол (Aleksić 2007, 167).

Јабучица типа К је присутна и на мачу пронађеном у Сремској Каменици код Новог Сада. Сечиво је оштећено, али се може определити у тип XIIIa. Мач из Музеја Војводине, ископан у Опову по типолошким карактеристикама је сличан са мачем из Вишњице, осим што је краћи, дужина сечива је 87 цм, док је дужина целог мача 112,5 цм. На сечиву има тауширане представе вука и друге четвороножне животиње. Са простора Балкана и југоисточне Европе, познато је још неколико мачева оваквих карактеристика. Мач из Музеја Босне и Херцеговине у Сарајеву, мач извађен из језера Балатон у Мађарској, мач из околине Копривнице у северној Хрватској и мачеви са неколико локалитета у Бугарској (Aleksić 2007, 56).

На сечиву мача из Глоговца око 4 цм од накрснице налази се тауширани симбол. Месинганом жицом представљени су спојени крст и срце (троугао) (сл. 3).

Крст као најважнији хришћански симбол, представљан је на мачевима и оружју уопште током целог средњег века. Крстови су стављани у разним техникама, гравирањем, тауширањем, утискивањем у разне делове мача. Представе грчког крста, латинског крста, крста на пиједесталима или уз неки натпис религиозног карактера, честа су појава (Aleksić 2007, 122).

Од друге половине 14. века, мачеви са специфичном представом на сечиву присутни су у целој Европи и Србији. Ради се о такозваним мачевима „вуковцима”, који су на сечиву имали представу вука. Ови мачеви су израђивани у мачарском еснафу баварског града Пасау. Пасауски мачари стављају овај знак на своје производе од 1340. године, када им херцог Албрехт Аустријски даје ово право повељом. Ово право потврђује и градски епископ, Алберт, 1368. године. Знак вука је вероватно преузет из градског грба, који је представљао гаранцију квалитета овог оружја. Мачеви потекли из радионица ових мајстора су имали стварну вредност, која се заснивала на вештој изради и употреби квалитетних материјала (Birtašević 1968, 83). То потврђује и чињеница да су мачеви „вуковци” ушли и у народну религију и предање, као оружје са такорећи магијском моћи (Бандић 2004, 96, 97). Други показатељ великог квалитета немачких мачева је то што је симбол пасауских мачара копиран на мачевима широм Старог света, од Француске, Италије, Шпаније, Пољске, па и ван граница Европе, на Кавказу, и у север- 
ној Африци (Birtašević 1968, 83). На мачевима „вуковцима” вук је приказан у силуети, гравирањем или тауширањем. Углавном је у покрету и са отвореним чељустима. Поред вукова, на мачевима су приказане још неке четвороножне животиње, такође у покрету. Неки аутори су у овим представама видели једнороге, коње, псе или велике мачке (Birtašević 1968, 87; Aleksić $2007,123,124)$. До сада је на простору Балкана и југоисточне европе пронађено укупно 45 мачева „вуковаца” (Aleksić 2007, 123). Стручњаци који су се бавили овом темом велики део мачева „вуковаца” определили су тако тек приликом накнадног проучавања, па се може очекивати да се овај број повећа (Birtašević 1968, 81).

Поред представа животиња, на мачевима „вуковцима” су се често налазили и симболи крста и срца, и ти мотиви могли су се различито комбиновати. Са простора Србије, представа срца и крста уз вука или једнорога налази се на четири мача (Aleksić 2007, 123, 124; Радичевић 2009, 82). Мач из Глоговца на сечиву има тауширане симболе, који се могу прочитати као спојени крст и срце (или цвет), али му недостају симболи четвороножне животиње који би га сигурно определили у „вуковца”.

У збирци средњовековног наоружања Завичајног музеја у Јагодини постоје и два мача, пронађена у близини Глоговца, и могу се довести у везу са њим. Један је пронађен у близини манастира Каленић, на манастирској земљи, поред села Каленићки Прњавор око 40 км од села Глоговац, док је други пронађен у Морави, код Ћуприје, на мање од 15 км од Глоговца. Поред тога што су пронађени у истом региону, ови мачеви су занимљиви јер као и мач из Глоговца на себи имају представу крста спојеног са срцем, без било какве четвороножне животиње (Cvetković 2009). Код ова два мача тауширани симбол се налази на обе стране сечива, док се код мача из Глоговца представа налази само на једној страни.

Мач из Каленића (сл. 4) публикован је сада већ давне 1983. године, мада је аутор у публикацији погрешно протумачио симбол срца и крста као представу четвороножне животиње, и определио мач као „вуковац” (Vetnić 1983, 143; Cvetković 2009, 238). Мач се према типолошко-морфолошким карактеристикама разликује од мача из Глоговца. Укупна дужина мача је 115 цм (Цветковић, Додић 2004, 23), сечиво мача припада Оукшутовом типу XVIa, док је јабучица опредељена у тип Н2.

Готово исту представу на сечиву има и мач пронађен у Морави код Ћуприје (сл. 5, сл. 6). Мач је стигао у музеј 1986. године, па није ушао у публикацију Саве Ветнића, нити га је обрадио Марко Алексић, у својој књизи о мачевима у југоисточној Европи. Мач је сличан оном из Кале- 

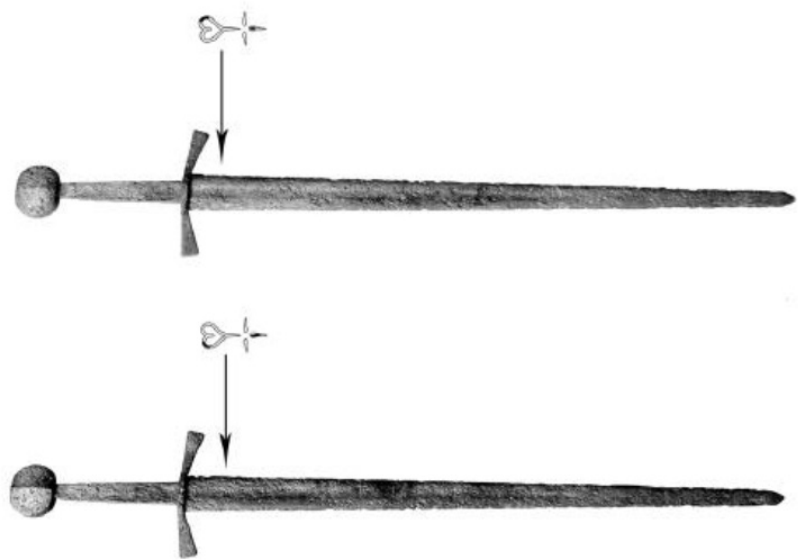

Сл. 4. Мач из Каленића, збирка Завичајног музеја Јагодина (према Cvetković 2009: 238, 239)

Fig. 4. Sword from Kalenić, collection of the Regional Museum Jagodina (according to Cvetković 2009: 238, 239)

нића, али има и занимљивих разлика. Мач је фрагментован, сечиво је поломљено и очувана дужина мача је 52 цм, док је само сечиво дуго 29 цм. Сечиво је опредељено у тип XVIa, са јабучицом типа Н1. Овај мач, поред симбола крста и срца (или цвета) на сечиву има и укуцано слово А у кругу (Cvetković 2009, 240).

У централној Србији је познат још један мач са сличним мотивом, ради се о мачу пронађеном у Западној Морави код села Пекчанице код Краљева (сл. 7). Приликом обраде мача, аутор је овај симбол који се налази на обе стране сечива представио као мотив цвета (руже). Мач типолошки одговара примерцима из збирке Завичајног музеја у Јагодини, са сечивом типа XVIa и јабучицом типа G или Н1. Мач је фрагментован, очувана дужина мача је 85,5 цм, очуваног дела сечива 61 цм (Марковић 1989б, 139).

Аутор чланка о мачевима из јагодинског музеја (Cvetković 2009, 239), у симболу на ова три мача, види ознаку радионице, и покушава да определи производњу као локалну, поткрепљујући такво мишљење аргументима да је мач из Каленића пронађен на потесу, под именом „ковачница”, где је наводно поред овог пронађено још неколико мачева и ножева, али је само овај доспео у музеј (Cvetković 2009, 240). У првој публикацији овог мача, Сава Ветнић каже да је укупно пронађено 10 мачева, а да су остаци гвоздене шљаке и отпадака од ковања и данас видљиви на површини (Vetnić 1983, 256). Међутим, на овом подручју нису вршена никаква даља истраживања. 

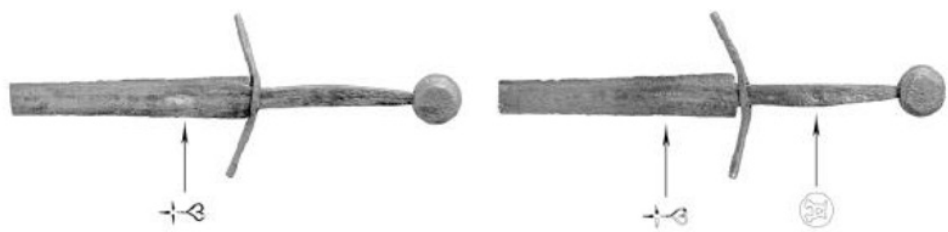

Сл. 5. Мач из Ћуприје, збирка Завичајног музеја Јагодина (према Cvetković 2009: 240)

Fig. 5. Sword from Ćuprija, collection of the Regional Museum Jagodina (according to Cvetković 2009: 240)

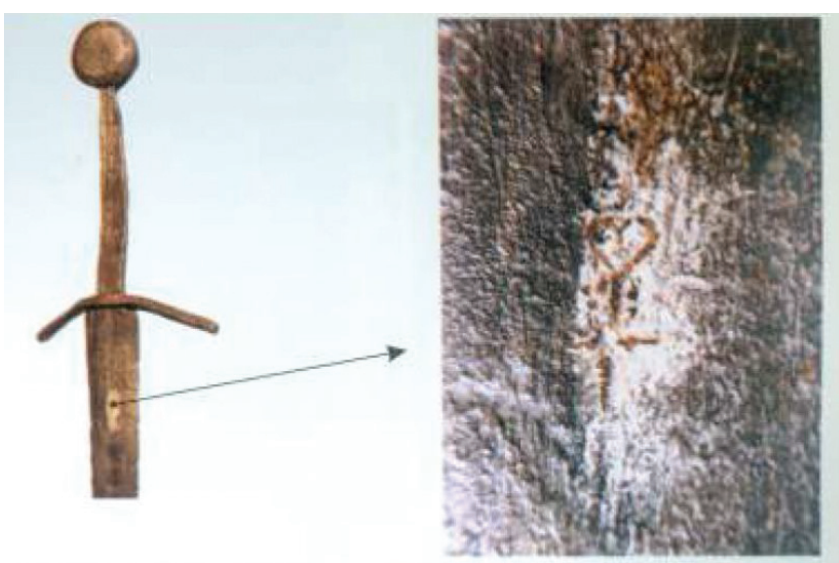

Сл. 6. Мач из Ћуприје, фотографија, збирка Завичајног музеја Јагодина (према: Цветковић, Додић 2004: 23)

Fig. 6. Sword from Ćuprija, collection of the Regional Museum Jagodina (according to Цветковић, Додић 2004: 23)

Сваки од ова четири тауширана знака на мачевима се разликују. На мачевима из Завичајног музеја у Јагодини крстасти симбол је доста тањи, а срце израженије и заобљених линија. На мачу из Пекчанице симбол заправо више личи на цвет, него на крст са срцем, мада га Марко Алексић види као крст на рачвастом постаменту (Aleksić 2007, 168). Уз напомену да цртежи можда и не представљају стварно стање, већ у великој мери лични став аутора.

Симбол срца на мачу из Завичајног музеја у Параћину оштријих је ивица, више четвртаст, што одговара техници тауширања у којој је изведен. Може да личи на стилизован хералдички штит, или као што је случај код мача из Пекчанице на цвет (Марковић 1989б, 139). Може се претпоставити да се ради о четири варијанте једног истог симбола, сваки пут изведеног другачије ручним алатом у кованом гвожђу, али без ваљаних аргумената да се ради о жигу ковачнице или мајстора. 

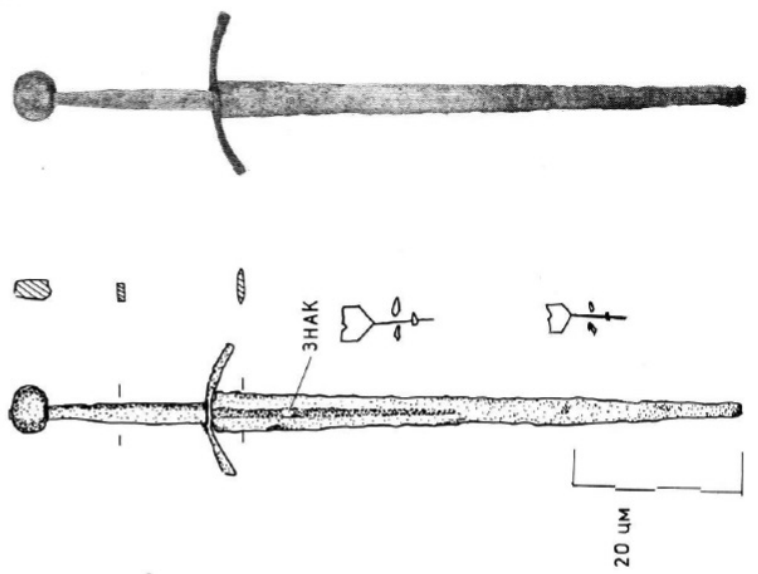

Сл. 7. Мач из Пекчанице, колекција Народног музеја Краљево (према Марковић 1989б: Т4, Т5)

Fig. 7. Sword from Pekčanica, collection of the National Museum Kraljevo (according to Марковић 1989б: Т4, Т5)

Нажалост, приликом конзерваторског третмана на мачу из Глоговца тауширани симбол је отпао са већим груменом кородираног материјала, па је данас остао сачуван само у фотодокументацији.

\section{Историјски и географски контекст налаза}

Долина Велике Мораве одувек је представљала један од најважнијих комуникацијских праваца на Балкану, спајајући југ Балканског полуострва са Панонском низијом и централном Европом. Сама долина је равна и проходна, оивичена Темнићем, Јухором, Црним врхом и шумадијским побрђем са запада те Буковиком, Бабом, Кучајским и Хомољским планинама на истоку. Захваљујући повољном географском положају и плодном земљишту Поморавље је најгушће насељено подручје централне Србије. Село Глоговац се налази на неколико километара од Велике Мораве, док је мач пронађен у самој реци, у близини села. На десетак километара низводно од Глоговца, налази се Багрдански теснац, улаз у Багрданску клисуру, која представља и савремену стратешки важну тачку, будући да кроз уску клисуру пролазе ауто-пут, железничка пруга и Морава (сл. 12). Другу важну комуникацију из овог правца представља пут који се од ушћа Мораве у Дунав, у близини Костолца (Viminacium), пружао кроз доњу Ресаву, и преко данашњег Свилајнца и села Медвеђа (Mansio Idium), излазио на Ћуприју (Horreum Margi). Овај комуникацијски правац је вероватно био важнији у 


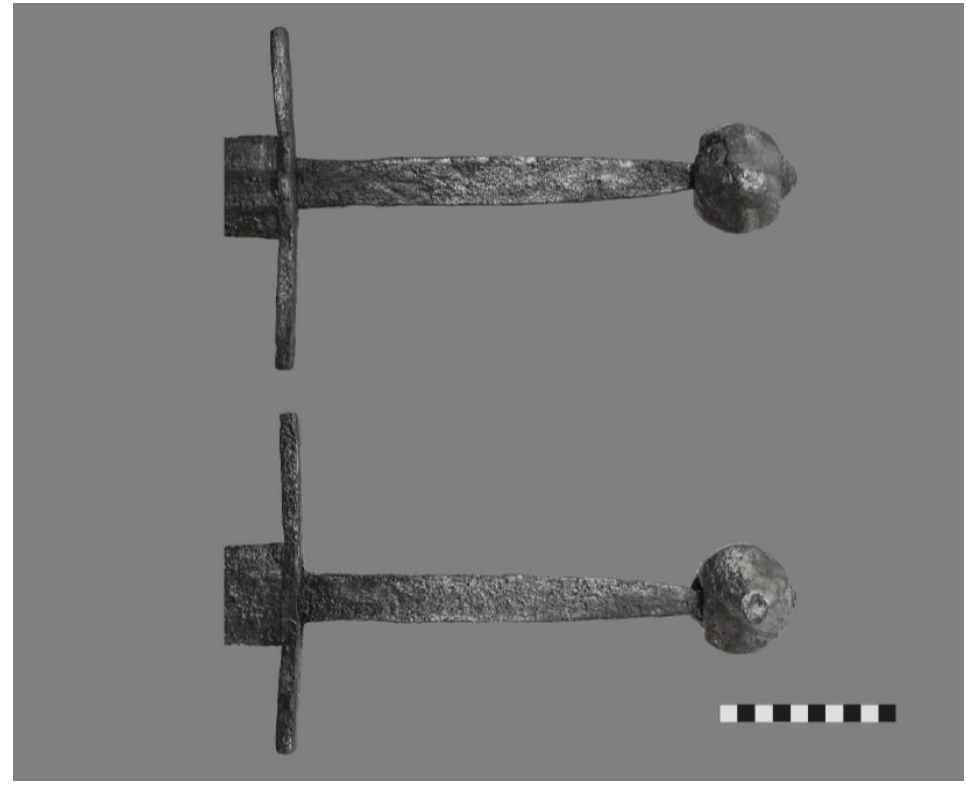

Сл. 8. Мач из Глоговца, накрсница, дршка и јабучица. Документација Завичајног музеја Параћин

Fig. 8. Sword from Glogovac, crossguard, handle and pommel, documentation of the Hometown Museum in Paraćin

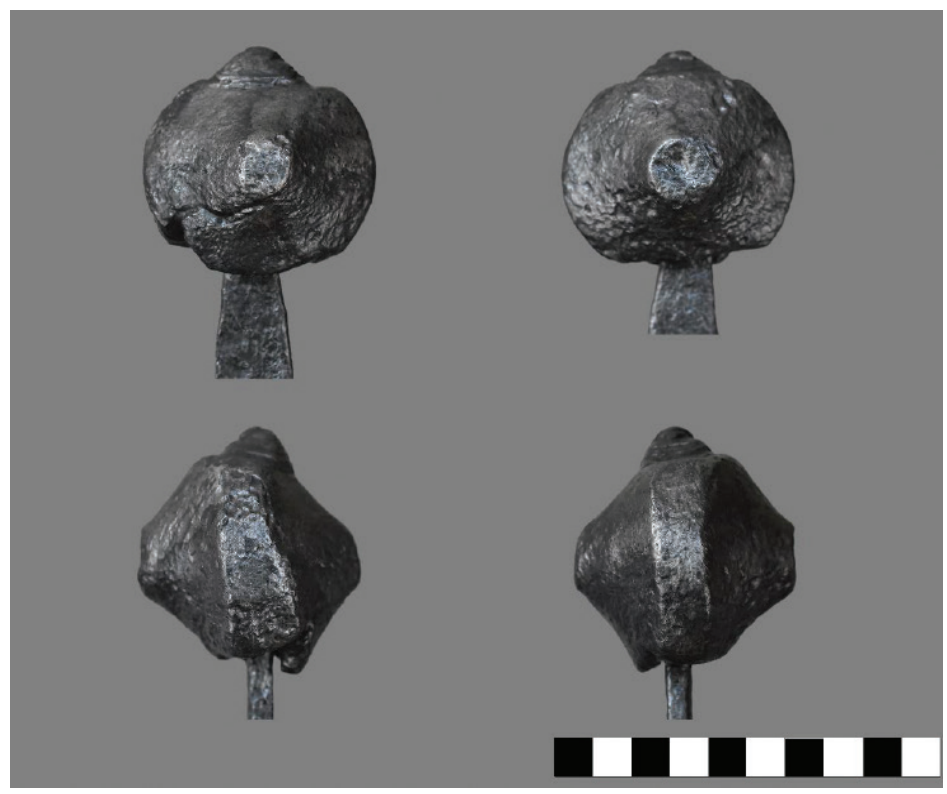

Сл. 9. Мач из Глоговца, јабучица, документација Завичајног музеја Параћин

Fig. 9. Sword from Glogovac, pommel, documentation of the Hometown Museum in Paraćin 

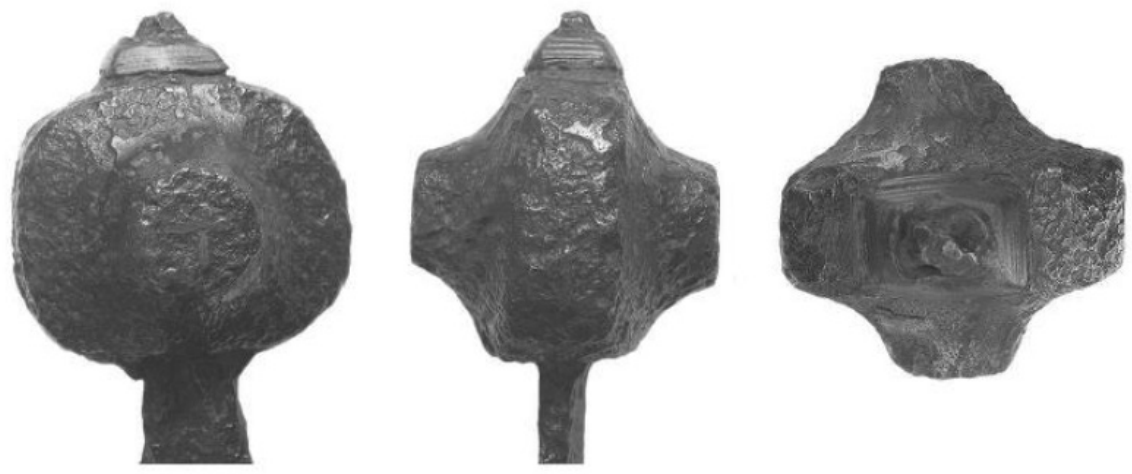

Сл. 10. Мач из Вишњице, јабучица, колекција Музеја града Београда (према Aleksić 2007: 55, fig. 17)

Fig. 10. Sword from Višnjica, pommel, collection of the Belgrade City Museum (according to Aleksić 2007: 55, fig. 17)

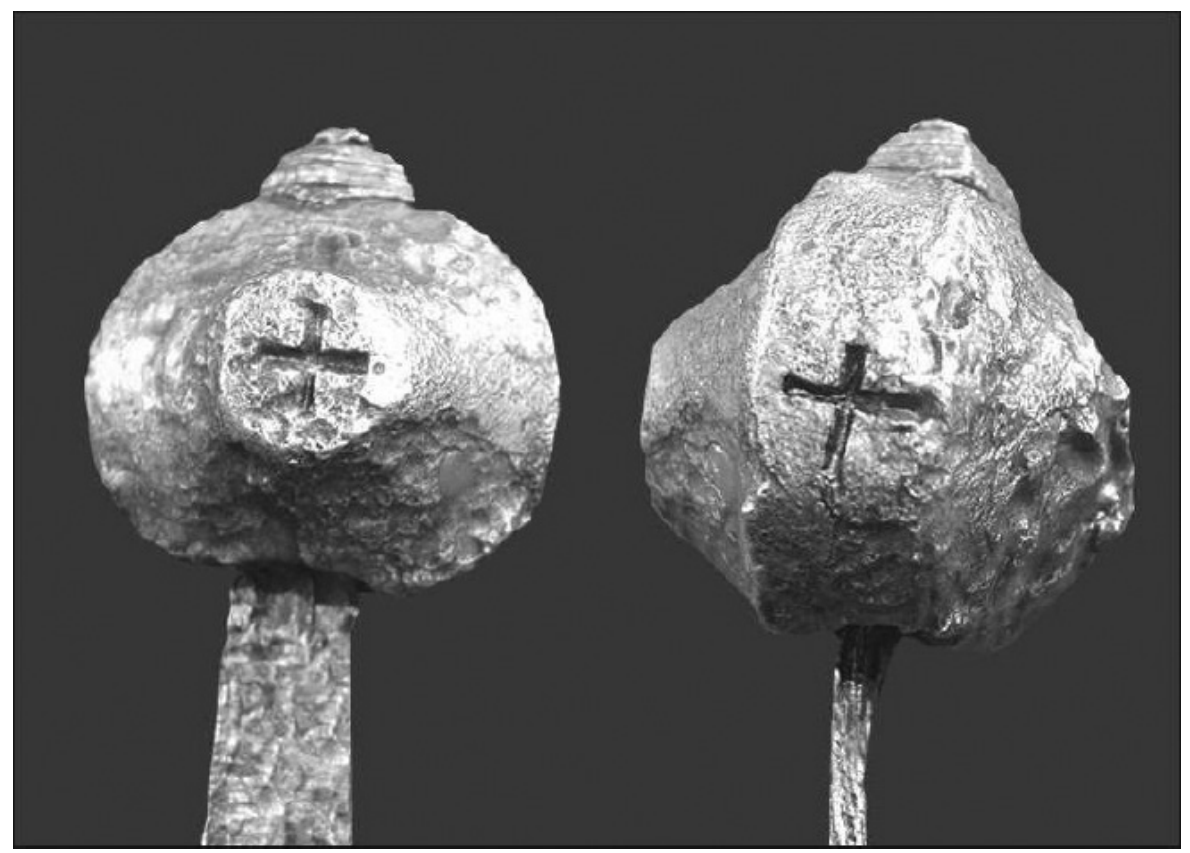

Сл. 11. Мач из Војног музеја у Београду, јабучица (према Aleksić 2007: 55 fig. 18)

Fig. 11. Sword from the collection of the Military Museum Belgrade, pommel (according to Aleksić 2007: 55 fig. 18) 


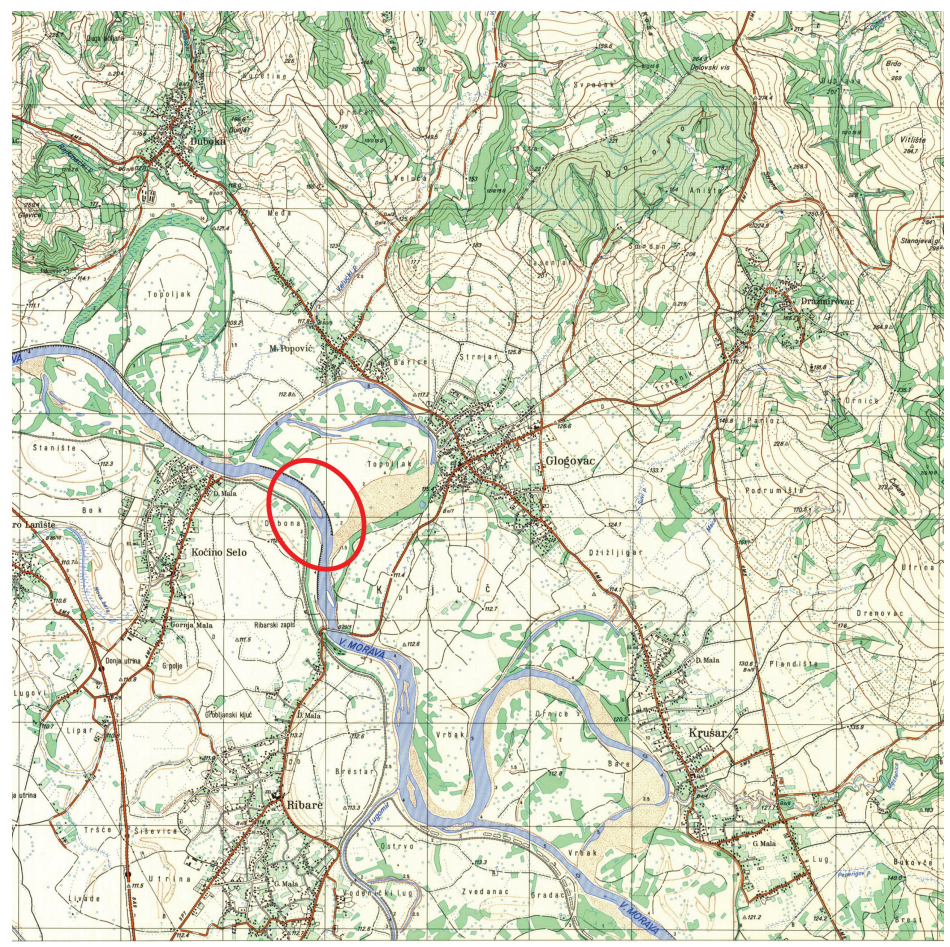

Сл. 12. Приближна локација проналаска мача из Глоговца

Fig. 12. Approximate location of the finding position of the sword from Glogovac

праисторији, антици и средњем веку него сам правац кроз долину Мораве и Багрдански кланац, и представља евентуални правац римског војничког пута, што показује велики број античких и средњовековних локалитета у околини, и историјска грађа (Јеремић 2011, 47, 48). Сама конфигурација терена у Србији отежава кретање великим војскама или групама другим правцима, осим долином Велике Мораве, па даље долином Нишаве ка истоку, или долином Јужне Мораве и Вардара према југу (Мишић, Ђокић 2011, 109-111; Filipović, Mladenović 2018, 19).

Област Поморавља се налази у средњовековној Србији од времена Стефана Немање и остаје њена централна територија до турских освајања.

У 12. и 13. веку ове области су организоване у облику жупе Поморавље. Током 14. и 15. века жупа Поморавље нестаје, а ова област добија нову територијалну организацију. Источно од Велике Мораве, до границе са Бугарском, односно Турском, простирала се Петрушка област. Петрушка област је основана између 1346. и 1355, када цар Душан жупану Вукославу даје на управу пустош Петрус. Жупана Вукослава наслеђује син, Цреп 
Вукославић, који као властелин крајишник влада овим простором. Војвода Цреп је познат као један од учесника битке на Дубравници, 1381. године, када је предводећи пограничну војску заједно са непознатим властелином Витомиром победио Турке у близини Параћина. Ова битка представља прву хришћанску победу над Турцима, још од пораза на Марици 1371. године. Војвода Цреп се не помиње у историјским изворима након тога, па неки аутори претпостављају да гине на Косову 1389. године. Након Црепа, Петрушко крајиште постаје власт, област са војном командом, под директном управом владара (Брмболић 2013, 93, 94; Благојевић 1987, 29-42; Шуица 2000, 117-119; Мишић 2010, 211).

Поред Петрушке области, на простору Поморавља се пружала и област Дубравница. Није познат тачан статус ове области, нити да ли се ради о жупи или земљи. Вероватно се налазила западно од Петрушке области, мада није јасно да ли је обухватала обе обале Мораве. Може се претпоставити да се пружала од Сталаћа на југу до Багрданског кланца на северу (Мишић, Ђокић 2011, 123).

Смрћу цара Душана 1355. и поразом на Марици 1371. године средњовековне српске државе улазе у доба политичке нестабилности, угрожене турском претњом, али и унутрашњим борбама између различитих обласних господара (Богдановић 2000, 7).

Такве околности, успешно користи Лазар Хребељановић. Он после кратке борбе са браћом Мрњавчевић и Николом Алтомановићем, уз подршку Цркве и одређене властеле, са којом је имао родбинске везе, постаје самодржавни кнез свим Србима, односно, самодржавни господин Србљем и Поморју Стефан велики кнез Лазар (Мишић 2014, 17).

Успоставивши власт у сливу три Мораве, Лазар одређује границе онога што се у савременој истороиграфији назива Моравска Србија (Михаљчић 2000, 21-28; Мишић 2014, 16,17). У релативном оквиру ових граница, под влашћу Лазаревих наследника са титулом Деспота, српска држава одолева турским освајањима све до 1459. и коначног пада Смедерева.

Стварање Моравске Србије значи померање тежишта српске државности на север, што ставља велико Поморавље, локацију проналаска мача у центар збивања, па чак и ратних дешавања.

Убрзо након Косовске битке 28. јуна, већ у октобру 1389. године, угарски краљ Жигмунд са војском упада на територију Србије. То понавља и у годинама које следе па 1397. године прелази Саву и долином Колубаре улази у Шумадију, у близину Рудника, где напада утврђења Борач и Честин (Ћирковић 2000, 47; Крстић 2017, 74, 75). Остало је непознато да ли у овим 
походима угарске снаге пролазе и кроз долину Мораве. У том периоду Стефан Лазаревић ратује против Угара и њихових савезника у две велике битке, на Ровинама 1395. и код Никопоља 1396. године.

Након смрти султана Бајазита, после битке код Ангоре 1402. године, у Турској је избио грађански рат, и током десетак година на власти се променило четири султана. У једном периоду деспот Стефан Лазаревић активно учествује у овим сукобима на страни тадашњег принца Мусе, па чак са својим јединицама ратује у бици код Космидиона у Златном рогу 15. јуна 1410. године. Принц Муса постаје султан 1411. године и од тада је у непријатељским односима са деспотом Стефаном. Непријатељство кулминира када 1413. године султан Муса креће у поход на српску деспотовину.

Муса је поход започео тако што је дошао у Сврљиг и Соколницу, одакле је протерао свог одбеглог поданика Хамзу. Одатле прелази у тадашњу Србију, где најпре заузима пограничне градове Болван и Липовац, а затим и Сталаћ. Након тога се вероватно негде у близини Крушевца, на Врбници, сукобљава са војском деспота Стефана и побеђује. Приликом овог похода Муса опседа или руши и следеће градове: Сврљиг, Болван, Липовац, Сталаћ, Крушевац, Копријан и Петрус. О опсади Петруса не пише ни деспотов биограф Константин Филозоф, тако да овај догађај остаје неизвестан (Мишић 1986, 78).

Поменути војни походи из друге половине 14. и почетка 15. векам предузети на простору Поморавља, могу послужити као општа илустрација збивања током којих је коришћено оружје попут мача из Глоговца, али се доспевање мача на дно Мораве, не може конкретно везати ни за један од ових догађаја.

\section{Закључна разматрања}

На основу типолошке и морфолошке анализе мача, са датим аналогијама, која је приказана у првом делу рада, мач из Глоговца припада групи великих средњовековних мачева, са сечивом типа XIIIa, накрсницом типа 1 и јабучицом типа К. Мачеви овог типа се у Србији могу датовати у 14. век, прецизније у његову другу половину, док су у централној и западној Европи они присутни од друге половине 13. и током целог 14. века, премда је највећи број примерака ових мачева датован у другу половину 14. века.

Према морфологији, мада не и према орнаментици на самом мачу, примерку из Глоговца је најсличнији мач пронађен у Дунаву код Вишњице, иако мачу из Вишњице недостаје накрсница (Aleksic 2007, 166 cat. no. 240). Мачеви из Завичајног музеја у Јагодини (Cvetković 2009) и Народног музеја у Краљеву (Марковић 1989б, 139) имају сличан орнамент на сечиву, али према типологији и димензијама не одговарају мачу из Глоговца. 
На основу тога што на мачу из Глоговца приликом пажљивог прегледања није уочен симбол вука или четвороножне животиње, већ само приказ крста са срцем, или цвета, за овај мач се са сигурношћу може рећи да не припада типу „вуковаца” јер је главни симбол мачара из Пасауа био управо вук (Birtašević 1968, 83).

На простор средњовековне Србије овакво оружје је могло стићи на више начина.

Већ од почетка владавине, краљ а касније и цар Душан започиње озбиљну реформу војног система и наоружања у Србији, модернизујући их по узору на војске западне Европе. Поред нових типова одбрамбене опреме, као што је оклоп типа корача и шлем типа барбута, као главно офанзивно оружје уводи се дуги мач. У средњовековној Србији и Приморју били су познати ковачи и мачари, али од времена цара Душана, у Србију долазе мајстори који вероватно праве нови тип оружја. Већ 1331. године у Призрен да прави мачеве за српског краља долази дубровачки мачар Мартоло (Алексић 2015, 21). Дубровачки изрази „,magna spata” и „spada granda”, познати са простора средњовековне Србије, одговарају западноевропским ,grant espées”, „grete swerdes", који су се односили на типове мачева какав је и мач из Глоговца.

Оружје је могло бити добављено и увозом, зна се да је Стефан Дечански 1313. године из Венеције и Дубровника поручио 108 мачева, а наоружање и оклопе наручивао је и Стефан Душан. Од 1341. до 1349. године увезено је на стотине комада различитих делова оклопа, штитова и мачева (Алексић $2015,16,22)$. Вероватно је велики број оружја дошао и са немачким најамницима који су боравили на двору цара Душана. (Алексић 2015, 10).

Порекло мача из Глоговца није домаће јер не постоје писани извори нити аргументовани материјални трагови о домаћој производњи оружја овог типа у средњовековној Србији током 14. и 15. века. Као што је то случај са неким другим типовима средњовековних мачева (Aleksić 2007, 97-103). Ако је мач из Глоговца произведен на простору Србије, мач је био производ унајмљених мачара који су долазили у средњовековну Србију на одређене периоде, као што је случај са дубровачким мачаром Мартолом, који је у Призрен дошао на две године (Петровић 1977, 128).

За крај може се претпоставити да је мач је стигао у Србију у другој половини 14. века и био дуго коришћен, јер приметно је да је сечиво истањено понављаним оштрењем. Током бурних догађаја друге половине 14. века приликом неког од војних похода бива изгубљен у Морави, а данас представља леп додатак збирци средњовековног наоружања Завичајног музеја Параћин. 


\section{БИБЛИОГРАФИЈА}

Aleksić, M. 2007. Medieval swords from southeastern Europe, material from 12th to 15th century, Belgrade: M. Aleksić.

Алексић, М. 2015. Реформа српске војске у време Стефана Душана, Војно историјски гласник 2015/2: 9-32.

Bandić, D. 2004. Narodna religija Srba u 100 pojmova, 2. ispravljeno izdanje. Beograd: Nolit.

Birtašević, M. 1968. Mačevi ,vukovci” u jugoslovenskim zbirkama, Vesnik Vojnog muzеја 13-14: 81-104.

Благојевић, М. 1987. Крајишта средњовековне Србије од 1371. до 1459. године, Историјски гласник 1-2: 29-42.

Богдановић, Д. 2000 Оживљавање немањићких традиција, у: Историја српског народа 2: ур. Ј. Калић: 7-21. Београд: Српска књижевна задруга.

Брмболић, М. 2013. Утврђење Петрус, Саопитења XLV: 93-109.

Vetnić, S. 1983. Medieval weapons and implements deriving from the middle Morava bassin, Balcanoslavica 10: 137-158.

Јеремић, Г. 2011. Средње поморавље у римско и касноримско доба: Деоница Idimum - Naissus у светлу археолошких налаза, у: Капија Поморављљ, ур. В. Стојанчевић, С. Мишић, А. Булатовић: 43-62. Варварин: Скупштина Општине Варварин, Историјски архив Крушевац.

Крстић, А. 2017. Угри и српско-угарски односи у биографији Деспота Стефана Лазаревића Константина Филозофа, Средњи век у српској науци, историји, књижевности и уметности VIII: 71-89.

Марковић, О. 1989а. Средњовековни мач из Заблаћа, Гласник Српског археолошког друштва 5: 154-155.

Марковић, О. 1989б. Средњовековни мачеви из околине Чачка и Краљева, Зборник Народног музеја, 18: 137-141.

Михаљчић, Р. 2000. Доба обласних господара, у: Историја српског народа 2, ур Ј. Калић, 21-36. Београд: Српска књижевна задруга.

Мишић, С. 1987. Поход султана Мусе на Деспотовину 1413. и источна српско-турска граница, Историјски гласник 1-2: 75-88.

Мишић, С. 2010 Петрус, у: Лексикон градова и тргова средњовековних српских земаља, ур. С. Мишић: 211. Београд Српска књижевна задруга.

Мишић, С. 2014. Од владарског кнеза до кнеза Срба - уздизање до владарске моћи, у: Власт и моћ - Властела Моравске Србије од 1365. до 1402. године ур. С. Мишић. Крушевац: Народна библиотека Крушевац Центар за историјску географију и историјску демографију Филозофског факултета Универзитета у Београду.

Мишић, С., Ђокић, Н. 2011. Капија Поморавља у историјској и војно стратегијској географији, у: Капија Поморавља, ур. В. Стојанчевић, С. Мишић, А. Булатовић: 109-152. Варварин: Скупштина Општине Варварин, Историјски архив Крушевац. 
Нинковић, В. 2009. Средњовековно оружје из збирки Народног музеја у Београду, Зборник Народног музеја XIX-1: 455 - 483.

Oakeshott, R. E. 1991. The Sword in the Age of Chivlary, London: The Boydell Press.

Петровић, Ђ. 1977. Оружје Србије у касном средњем веку, у: Историја примењене уметности код Срба I, ур. Н. Андрејевић-Кун: 123-153. Београд: Музеј примењене уметности.

Поп Лазић, П. 1983. Каталог средњовековног оружја и опреме у Историјском музеју Србије. Зборник Историјског музеја Србије 20: 161-194.

Прокић, Р. 1986. Средњовековна архитектура Петрушке области, Крагујевац: Светлост, Завод за заштиту споменика културе Крагујевац.

Радичевић, Д. 2009. Средњовековни мач из Дупљаје, Гласник Српског археолошког друштва 25: 77-90.

Ruttkay, A. 1975. Waffen und reiterasrüstung des 9. bis zur ersten halfte des 14. Jahrhunderts in der Slowakei I, Slov. Arch. XXIII-1, 1975, 119-216,

Ћирковић, С. 2000. Године кризе и превирања, Историја српског народа 2, ур. J. Калић: 47-64. Београд: Српска књижевна задруга.

Filipović, V., Mladenović, O. 2019. Prirodne karakteristike severnog Stiga i njegov strateški značaj u praistoriji i ranoj istoriji, u: Viminacijum u praistoriji: iskopavanja 2005-2015, ur. A. Kapuran, A. Bulatović, S. Golubović, V. Filipović: 11-24. Beograd: Arheološki institut.

Цветковић, Б., Додић, С. 2004. Пет десетлећа ентузијазма, посебно издање поводом педесет година рада Завичајног музеја у Јагодини, 1954 - 2004. Јагодина: Завичајни музеј у Јагодини.

Cvetković, B. 2009. Two medieval swords from the Regional Museum in Jagodina, Старинар LIX: 237-246.

Šercer, M. 1976. Mačevi, bodeži, noževi u Povijesnom muzeju Hrvatske, katalog izložbi 14, Zagreb, Povijesni muzej Hrvatske.

Шкриванић, Г. 1957. Оружје у средњовековној Србији, Босни и Дубровнику, Београд: Научно дело.

Шуица, М. 2000. Немирно доба, српског средњег века. Властела српских обласних господара, Београд: Службени лист СРЈ. 


\section{Filip Stefanović}

Homeland Museum in Paraćin

\section{MEDIEVAL SWORD FROM GLOGOVAC}

Keywords: Glogovac, Morava River, Morava Valley, sword, Late Middle Ages

The author analyses a sword found during the extraction of gravel from the Morava River, near the village of Glogovac in the Municipality of Jagodina. The sword is found in rather good condition, though fragmented into two pieces by an excavator machine during the extraction. The sword is exceptionally long, similar to swords used in medieval Europe during the $14^{\text {th }}$ century. It has a XIIIa type of blade, which is one of the most common types within South-eastern Europe. The pommel of this sword is categorized as Type $\mathrm{K}$, according to the typology by Oakeshott. Almost all swords with Type K pommels from South-eastern Europe are large swords with a Type XIIIa blade, like this example, or Type XVIa blade. The most recognisable feature of this sword is a mark of a cross and heart (or flower) on the blade. The mark was placed as an inlay in the sword with brass wire, forged into the blade. The most prominent inscribed mark on medieval sword blades is the running wolf of Passau, a German city with a blacksmiths' guild that used the wolf from the town's coat-of-arms as the guild mark. There is no proof that this sword was forged in Passau since the mark is different. All of the morphological features of the sword have analogies from the territory of medieval Serbia. The sword can be dated into the second half of the $14^{\text {th }}$ century. 